\title{
Erratum
}

Cold Spring Harb Perspect Med 6: a026278 (2016)

\section{Erratum: p53 and Medulloblastoma}

\author{
Vijay Ramaswamy, Carolina Nör, and Michael D. Taylor
}

In earlier versions of this article, the word "Medulloblastoma" was misspelled in the title. The publisher apologizes for this error. The PDF and HTML versions of the article have now been corrected.

doi: $10.1101 /$ cshperspect.a029579

Copyright (C) 2016 Cold Spring Harbor Laboratory Press; all rights reserved; doi: 10.1101/cshperspect.a029579

Cite this article as Cold Spring Harb Perspect Med 2016;6:a029579 


\section{$\&_{\mathrm{CSH}}^{\infty} \&$ Cold Spring Harbor $\stackrel{\text { PERSPECTIVES }}{\longrightarrow \infty_{\infty}}$ Perspectives in Medicine}

\section{Erratum: p53 and Medulloblastoma}

Vijay Ramaswamy, Carolina Nör and Michael D. Taylor

Cold Spring Harb Perspect Med 2016; doi: 10.1101/cshperspect.a029579

Subject Collection

For additional articles in this collection, see http://perspectivesinmedicine.cshlp.org/cgi/collection/ 